\title{
ALBAFLAVENONE, A SESQUITERPENE KETONE WITH A ZIZAENE SKELETON PRODUCED BY A STREPTOMYCETE WITH A NEW ROPE MORPHOLOGY
}

\author{
Hanne Gürtler* and Rita Pedersen \\ Microbiology, Novo Nordisk A/S, Novo Alle, \\ Bagsværd DK-2880, Denmark \\ Uffe Anthoni, Carsten Christophersen and Per H. Nielsen \\ Marine Chemistry Section, The H. C. Ørsted Institute, University of Copenhagen, \\ Universitetsparken 5, DK-2100 Copenhagen, Denmark \\ Elizabeth M. H. Wellington \\ Department of Biological Sciences, University of Warwick, \\ Coventry CV4 7AL, UK \\ Christian Pedersen \\ Organic Chemistry, The Technical University of Denmark, \\ Lundtoftevej 100, DK-2800 Lyngby, Denmark

\section{KLAUS BoCK} \\ Department of Chemistry, Carlsberg Laboratory, \\ GI. Carlsberg Vej 10, DK-2500 Valby, Denmark
}

(Received for publication June 28, 1993)

\begin{abstract}
A novel antibiotic $\alpha, \beta$-unsaturated sesquiterpene ketone, albaflavenone with a zizaene skeleton was isolated from a morphologically novel, highly odorous Streptomyces species which was identified with the species group $S$. albidoflavus, cluster 1 . The new compound, partly responsible for the odour, was assigned the structure of $2 R^{\prime}, 6,7,7$-tetramethyl-1 $S^{\prime}, 8 R^{\prime}$-tricyclo-[6.2.1.0 $\left.{ }^{1,5}\right]$ undec-5-en-4-one based on spectroscopic studies including 2D NMR (COSY, HETCOR, ROESY, NOE-difference) experiments.
\end{abstract}

The majority of known terpenoids are produced by eukaryotic organisms. However, a variety of actinomycetes, most notably members of the genus Streptomyces, produce sesquiterpenes which have been implicated in the production of earthy odours in water ${ }^{1,2)}$, and in soil ${ }^{3)}$. These were identified as geosmin, methylisoborneol in combination with the heterocyclic 2-isopropyl-3-methoxy-pyrazine ${ }^{4)}$. Other odorous sesquiterpenes have been isolated from broths of streptomycetes and include cadin-4-ene-1-ol ${ }^{5)}$, selina$4(14), 7(11)$-diene-9-ol(1) ${ }^{6}$ and mucidone ${ }^{7)}$. The antibiotic, arenamycin, is one of the few sesquiterpenes produced by streptomycetes reported to have biological activity ${ }^{8)}$. This metabolite, also known as pentalenolactone, is biosynthesized via the enzymatic cyclization of farnesyl pyrophosphate to pentalenene. ${ }^{9}$

We wish to report the isolation of an unusually odoriferous actinomycete which produces a novel sesquiterpene, albaflavenone, identified as 2,6,7,7-tetramethyltricyclo[6.2.1.0 $\left.0^{1,5}\right]$ undec-5-en-4-one. The characteristics of this strain together with the isolation and identification of the novel metabolite and its antibiotic activity are described. 


\section{Materials and Methods}

NMR spectra were recorded on a Bruker AMX 600 spectrometer and IR on a Perkin Elmer 1760X FT-IR spectrophotometer. UV spectra originate from a Hewlet Packard 8452A Diode Array instrument and MS on a JEOL JMS-HX/HX 110A tandem mass spectrometer. A Hewlett Packard P 5890 gas chromatograph coupled to a VG 12-250 mass spectrometer was used for GC-MS investigations. HPLC was monitored with a Hewlett Packard 5880 HPLC detection system.

\section{Isolation and Taxonomy of Producing Strain}

Starch casein medium ${ }^{10}$ and the membrane filter method ${ }^{11)}$ were used for isolation from seeds. The strain, DSM 5415 was characterized and identified using the methods of Williams et al. ${ }^{12}$. A $16 S$ rRNA Streptomyces genus probe as defined by STACKEBRANDT et al. ${ }^{13)}$ was used to confirm generic status of DSM 5415 using the method of STACKEBRANDT et al. ${ }^{13)}$. Whole cell hydrolysates were analysed by TLC ${ }^{14)}$, and chemotaxonomic analysis was carried out by the German Collection of Microorganisms and Cell Cultures (DSM) and included analysis of cell wall amino acids, menaquinone type and its abundance in the cytoplasmic membrane and whole cell fatty acids.

\section{Fermentation}

Two $\mathrm{ml}$ of a spore suspension of DSM 5415 were inoculated into $500-\mathrm{ml}$ baffled Erlenmeyer flasks containing $100 \mathrm{ml}$ of the medium which consisted of $(\mathrm{g} /$ liter $)$ : soy tone 40.0 , potato flour $100.0, \mathrm{Na}_{2} \mathrm{HPO}_{4}$ 12, BAN $120 \mathrm{~L}$ (Novo Nordisk A/S) $0.2 \mathrm{ml}$, pluronic (antifoam) $0.2 \mathrm{ml}, \mathrm{pH} 7.0$. The flasks were incubated at $30^{\circ} \mathrm{C}$ for 5 days at $280 \mathrm{rpm}$.

\section{Isolation of Albaftavenone}

The whole broth (2.5 liters) was extracted with $3 \times 400 \mathrm{ml}$ redistilled EtOAc at $\mathrm{pH}$ 6.6. The extract was dried over $\mathrm{MgSO}_{4}$ (30 minutes) and after filtration, concentrated in vacuo. The dried residue (2.6 g) was extracted with $5 \times 10 \mathrm{ml} n$-heptane-EtOAc $(1: 1)$, yielding a yellow oil $(139 \mathrm{mg})$, which was subjected to initial purification on a LiChroprep Lobar Si 60 column of $40 \sim 63 \mu \mathrm{m}$ (Merck) with EtOAc- $n$-heptane $2: 3$. The effluent was monitored at $260 \mathrm{~nm}$, and each component investigated by GC-MS and by analytical HPLC (RP 18, $5 \mu \mathrm{m}$ column, acetonitrile - water $80: 20$ ) monitored with a photo diode array detector. A fraction ( $3.2 \mathrm{mg}$ displaying a signal at $\mathrm{m} / \mathrm{z} 218$ ) was further purified by preparative HPLC, using a LiChrosorb Hibar RP 18 column $(25 \times 1 \mathrm{~cm}, 7 \mu \mathrm{m})$ with acetonitrile-water $(85: 15)$ to give $1.1 \mathrm{mg}$ pure albaflavenone.

The following fraction from the initial chromatography $(2.8 \mathrm{mg})$ contained a component with $\mathrm{M}^{+}$at $m / z 220$, believed to represent the alcohol corresponding to albaflavenone. Further purification of this fraction gave $400 \mu \mathrm{g}$ of an impure compound which is still under investigation.

\section{Tests for Antibiotic Activity}

The in vitro activity of albaflavenone was tested against Bacillus subtilis ATCC 6633 which was grown in $10 \mathrm{ml}$ tubes each containing $1 \mathrm{ml}$ of a medium which consisted of $(\mathrm{g} /$ liter): Trypticase (BBL) 20.0, yeast extract (Difco) 5.0, $\mathrm{FeCl}_{2} \cdot 4 \mathrm{H}_{2} \mathrm{O} 0.006, \mathrm{MnCl}_{2} \cdot 4 \mathrm{H}_{2} \mathrm{O} 0.001, \mathrm{MgSO}_{4} \cdot 7 \mathrm{H}_{2} \mathrm{O} 0.015, \mathrm{pH}$ 7.3. Different concentrations of pure albaflavenone were added to the tubes. The tubes were incubated at $30^{\circ} \mathrm{C}$ with shaking ( $300 \mathrm{rpm}$ ) for 20 hours. The lowest concentration that inhibited growth of $B$. subtilis was recorded as the MIC.

\section{Results}

Taxonomy of producer

The producing strain DSM 5415 was isolated from corn seed. The generic identity was confirmed as Streptomyces by the presence of LL-DAP and glycine in the cell wall and a positive signal was obtained following hybridization of RNA with the ${ }^{32} \mathrm{P}$-labelled $16 S$ rRNA genus probe. The predominant 
menaquinones were MK-9 $\left(\mathrm{H}_{4}, \mathrm{H}_{6}, \mathrm{H}_{9}\right)$ typical for the Streptomyces genus ${ }^{15)}$. However, an atypical feature was noted in the quantitative distribution of $\mathrm{MK}-9\left(\mathrm{H}_{6}\right)$, as this is usually the most abundant meaquininone but in DSM $5415 \mathrm{MK}-9\left(\mathrm{H}_{4}\right)$ gave the highest peak. This difference was not regarded as sufficient to affect the generic identification as the relative abundance of the menaquinones has been shown to vary with stages in the growth cycle ${ }^{15)}$. The fatty acid profile showed major amounts of the iso- and anteiso-fatty acids characteristic of the genus Streptomyces with major amounts of the fatty acid methyl esters with chain length 16:0, iso-16:0, anteiso-15:0, anteiso-17:0, iso-14:0, iso-15:0, in order of abundance. DSM 5415 produced a stable mycelium but the long chains of spores were aggregated into ropes observed by scanning electron microscopy (SEM) (Figs. 1b, c, d); these ropes were clearly visible under the light microscope (Fig. 1a). The substrate mycelium and non-sporulating aerial mycelium also formed ropes (Fig. 1b). Phenotypically DSM 5415 was identified with the species-group Streptomyces albidoflavus, cluster 1 , with an identification score for the Willcox probability of 0.988 , taxonomic distance $(\delta)$ of 0.417 and SE of $\delta 2.105$. The spore mass was powdery, yellow to cream on all media used for identification tests. An unusual, strong odour was produced both on solid and in liquid media. DSM 5415 matched to the group $S$. albidoflavus as defined by WiLliams et al. ${ }^{15)}$ in vol. 4 of BerGEY's manual, the diagnostic features for which are given by WILLIAMs et al. ${ }^{15)}$. This positive identification showed that the strain shared the features most diagnostic for the group including spore chain Rectiflexibles, smooth spore surface, no production of a diffusible pigment, melanin negative, antibiosis against fungi only (those given in Ref. 15), positive scores for lipolyisis, elastin, arbutin and xanthine degradation, resistance to penicillin,

Fig. 1. Novel rope-forming morphology of DSM 5415 growing on oatmeal agar.

(a) Light micrograph showing clear roping of aerial spore chains, unfixed, growing on a glass coverslip ( $\times 300$ ). (b) Aerial mycelium ropes observed by SEM. (c) Rope formation by aggregation of spore chains (SEM). (d) Chains of ropes comprising rope structure (SEM).

(a)

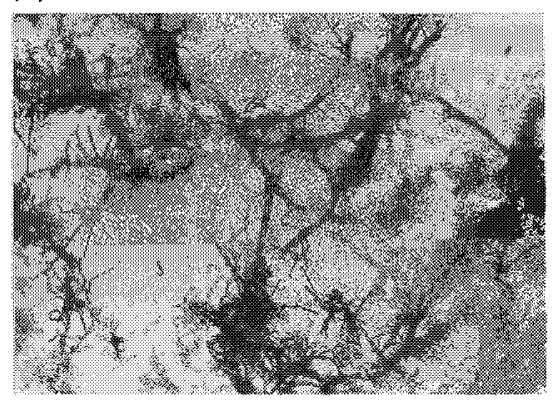

(c)

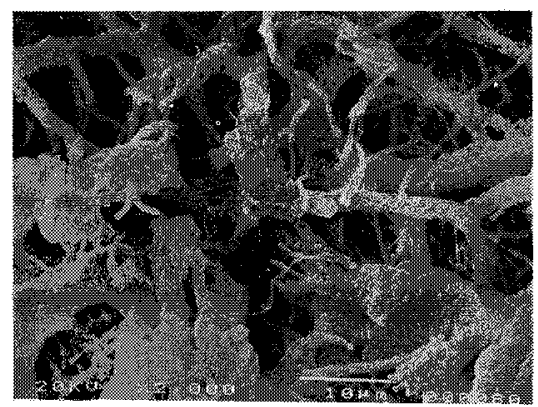

(b)

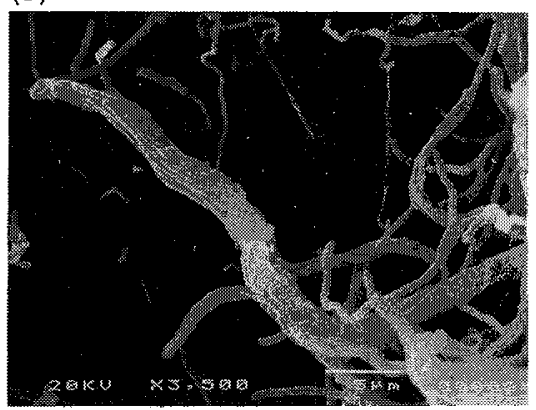

(d)

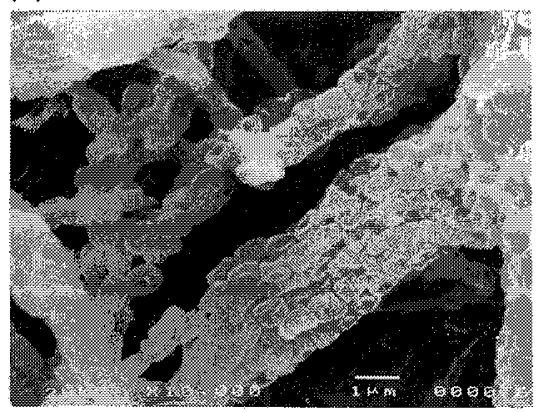


$7 \% \mathrm{NaCl}$, phenol $0.1 \%$, potassium tellurite $0.001 \%$, thallous acetate $0.001 \%$ and utilization of mannitol. Negative scores for diagnostic characters were obtained for presence of soluble pigments and substrate mycelial pigments other than yellow-brown, ability to degrade licithin, pectin, hippurate, resistance to neomycin, growth at $45^{\circ} \mathrm{C}$, utilization of L-hydroxyproline, L-rhamnose, raffinose, dextran and xylitol. The sole atypical character was the inability to produce $\mathrm{H}_{2} \mathrm{~S}$.

\section{Structure Elucidation of Albaflavenone}

The colourless solid ketone, named albaflavenone, gave a parent ion in the EI-HR-MS at $m / z 218.1664$ (Calcd for $\mathrm{C}_{15} \mathrm{H}_{22} \mathrm{O} 218.1671$ ). All fifteen carbon atoms were resolved in the ${ }^{13} \mathrm{C}$ NMR spectrum (Table 1). DEPT experiments established the presence of 4 methyl, 4 methylene, 2 methine, and 2 saturated quaternary carbon atoms and three $s p^{2}$ hybridized carbon atoms indicating a sesquiterpenoid structure. The proton spin systems were analysed using homonuclear decoupling and COSY experiments. A CHcorrelation experiment using inverse detection (HMQC sequence ${ }^{16)}$ ) served to connect the carbon and proton resonances as shown in Table 1. According to the ${ }^{13} \mathrm{C}$ NMR data the three $s p^{2}$-hybridized carbon atoms participate in an $\alpha, \beta$-unsaturated ketone moiety. This was substantiated by the UV high intensity band $\left(\lambda_{\max }^{\mathrm{E} \text { tOH }} 261 \mathrm{~nm}, \varepsilon 7,000\right)$ compared to findings for $\left.\Delta^{8,14}\right)$-ergostenol-15-one acetate ${ }^{17)}\left(\lambda_{\max }^{\mathrm{EtOH}} 259 \mathrm{~nm}\right.$, $\varepsilon 13,300)$ and two strong IR vibrations $\left(v^{\mathrm{KBr}} 1704\right.$ and $1619 \mathrm{~cm}^{-1}$ for $\mathrm{C}=\mathrm{O}$ and $\mathrm{C}=\mathrm{C}$, respectively). The remaining three degrees of unsaturation demand the presence of a tricyclic system.

The ${ }^{1} \mathrm{H}$ NMR chemical shift of the allylic $13-\mathrm{CH}_{3}$ group $(2.09 \mathrm{ppm})$ predicts this group to reside at the $\beta$-position of the $\alpha, \beta$-unsaturated carbonyl system. This was substantiated by $\mathrm{CH}$-correlation with inverse detection (HMQC sequence ${ }^{16)}$ ), optimized for long range couplings, revealing the 8-CH-7-C(14$\left.\mathrm{CH}_{3}, 15-\mathrm{CH}_{3}\right)-6-\mathrm{C}\left(13-\mathrm{CH}_{3}\right)=\mathrm{C}-5$ sequence. The position of the methyl bearing carbons of this sequence was supported by the observation of a $2 \%$ enhancement of the geminal methyl groups at $\mathrm{C}-7$ by irradiation at the position of the signal originating from $13-\mathrm{CH}_{3}$. The spin system $11-\mathrm{CH}_{2}-8-\mathrm{CH}-9-\mathrm{CH}_{2}-10-\mathrm{CH}_{2}$

Table 1. NMR data of albaflavenone.

\begin{tabular}{|c|c|c|c|c|}
\hline Position & $\delta_{\mathrm{C}}$ & $\delta_{\mathrm{H}}$ & $J$ & ROE \\
\hline 1 & $51.8 \mathrm{~s}$ & & & \\
\hline 2 & $33.3 \mathrm{~d}$ & 2.20 & $6.8,13.2,7.3$ & 3-Ha, 3-Hb \\
\hline \multirow[t]{2}{*}{3} & $47.4 \mathrm{t}$ & a 2.40 & $7.3,17.3$ & $2-\mathrm{H}, 3-\mathrm{Hb}$ \\
\hline & & b 2.02 & $13.2,17.3$ & $2-\mathrm{H}, 3-\mathrm{Ha}, 12-\mathrm{H}$ \\
\hline 4 & $207.4 \mathrm{~s}$ & & & \\
\hline 5 & $138.8 \mathrm{~s}$ & & & \\
\hline 6 & $153.0 \mathrm{~s}$ & & & \\
\hline 7 & $42.7 \mathrm{~s}$ & & & \\
\hline 8 & $46.2 \mathrm{~d}$ & 1.91 & $6.8,5.4$ & $9-\mathrm{Hb}, 11-\mathrm{Ha}, 14-\mathrm{H}, 15-\mathrm{H}$ \\
\hline \multirow[t]{2}{*}{9} & $24.4 t$ & a 1.75 & $3.5,6.8,11.4,13.8$ & $14-\mathrm{H}, 8-\mathrm{H}, 10-\mathrm{Hb}$ \\
\hline & & b 1.79 & $9.1,6.3,1.8,13.8$ & $8-\mathrm{H}, 10-\mathrm{Ha}, 11-\mathrm{Ha}$ \\
\hline \multirow[t]{2}{*}{10} & $29.6 t$ & a 1.61 & $6.3,11.4,11.3$ & $11-\mathrm{Ha}, 9-\mathrm{Ha}, 10-\mathrm{Hb}$ \\
\hline & & b 1.39 & $2.3,9.1,11.3$ & $10-\mathrm{Ha}, 9-\mathrm{Hb}$ \\
\hline \multirow[t]{2}{*}{11} & $37.0 \mathrm{t}$ & a 1.70 & $5.4,10.9$ & $9-\mathrm{Ha}, 10-\mathrm{Ha}, 11-\mathrm{Hb}$ \\
\hline & & b 1.56 & $1.8,10.9,2.3$ & 11-Ha, 14-H \\
\hline 12 & $14.2 \mathrm{q}$ & 1.07 & 6.8 & $2-\mathrm{H}, 3-\mathrm{Ha}, 3-\mathrm{Hb}$ \\
\hline 13 & $13.0 \mathrm{q}$ & 2.09 & & 15-H, 14-H \\
\hline 14 & $28.3 \mathrm{q}$ & 1.15 & & $11-\mathrm{Hb}, 8-\mathrm{H}, 13-\mathrm{H}, 15-\mathrm{H}$ \\
\hline 15 & $24.5 \mathrm{q}$ & 1.12 & & $14-\mathrm{H}, \mathrm{13}-\mathrm{H}, 8-\mathrm{H}, 9-\mathrm{Hb}$ \\
\hline
\end{tabular}

Spectra were measured in $\mathrm{CDCl}_{3}$ solution at $600 \mathrm{MHz}$ for protons and at $150.9 \mathrm{MHz}$ for carbon. Chemical shifts are expressed in ppm relative to internal TMS and $J$ in $\mathrm{Hz}$. 
lacks couplings between $8-\mathrm{H}$ and 9-Hb and $11-\mathrm{Hb}$. Molecular models demonstrate the $\mathrm{C}-8-\mathrm{H}$ bond to be orthogonal to both the $\mathrm{C}-9-\mathrm{Hb}$ and the $\mathrm{C}-11-$ $\mathrm{Hb}$ bonds. $\mathrm{C}-11-\mathrm{Hb}$ is in a "W" relationship to $\mathrm{C}-10-\mathrm{Hb}$ and $\mathrm{C}-9-\mathrm{Hb}$ giving rise to long range couplings. The presence of the sequence $12-\mathrm{CH}_{3}-$ 2-CH-3- $\mathrm{CH}_{2}-\mathrm{C}-4$ was deduced from the data obtained by the inverse detection techniques mentioned above. Further support for these assignments was obtained from a ROESY experiment (Table 1). In addition these data clarified most of the relative stereochemistries since cross peaks between the signals at $1.75 \sim 1.61 \sim 1.70 \mathrm{ppm}$ define the cis relationship of protons $9-\mathrm{Ha}, 10-\mathrm{Ha}$, and $11-\mathrm{Ha}$. Similarly cross peaks between the resonances at 1.15 and 1.56 and $1.91 \mathrm{ppm}$, respectively, demonstrate the cis relationship between $14-\mathrm{CH}_{3}, 11-\mathrm{Hb}$ and $8-\mathrm{H}$. Cross peaks between resonances at 1.12
Fig. 2. Structure of 2,6,7,7-tetramethyltricyclo$\left[6.2 .1 .0^{1,5}\right]$ undec-5-en-4-one.

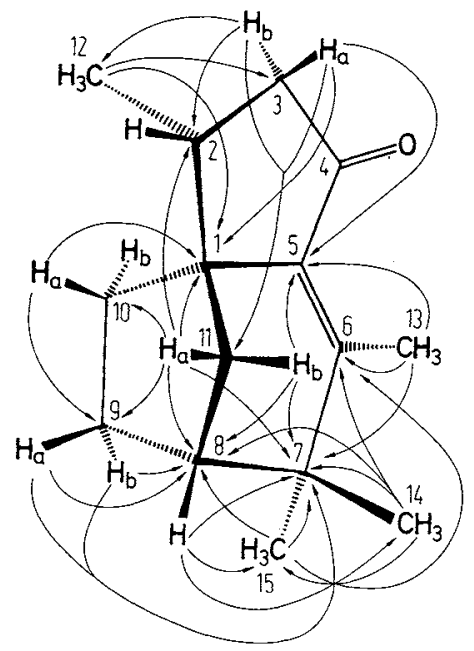

The results of the HMQC correlations are shown by arrows.

and 1.79 and 1.91 shows $15-\mathrm{CH}_{3}$ to be spatially close to $9-\mathrm{Hb}$ and $8-\mathrm{H}$. No cross peaks appeared between the resonances of $12-\mathrm{H} \sim 10-\mathrm{H}$ and $2-\mathrm{H} \sim 11-\mathrm{H}$. However, NOE difference experiments demonstrated enhancement between $2-\mathrm{H}$ and $11-\mathrm{Hb}$ and between $12-\mathrm{H}$ and $10-\mathrm{Ha}$. Inspection of models disclose that the enhancements observed are only consistent with the proposed structure provided the relative configuration is $1 S^{\prime}, 2 R^{\prime}, 8 R^{\prime}$. Based on these deductions we assign the structure of albaflavenone as $2 R^{\prime}, 6,7,7-$ tetramethyl-1 $S^{\prime}, 8 R^{\prime}$-tricyclo-[6.2.1.0 $\left.0^{1,5}\right]$ undec-5-en-4-one analogous to the saturated sesquiterpene skeleton zizaane (2,6,7,7-tetramethyl-[6.2.1.0 $\left.0^{1,5}\right]$ undecane). The skeleton of albaflavenone has previously been obtained synthetically from khusimol ${ }^{18)}$. The structure of albaflavenone in Fig. 2 is not intended to depict the absolute stereochemistry, which is at present unknown. Albaflavenone exhibits $[\alpha]_{\mathrm{D}}^{20} 120^{\circ}$ (EtOH, $c 0.024)$ and $\mathrm{CD} \Delta \varepsilon_{256}-2.15$ and $\Delta \varepsilon_{350} 0.87 \mathrm{M}^{-1} \mathrm{~cm}^{-1}\left(\mathrm{EtOH}, 1.43610^{-4} \mathrm{M}\right.$ ).

GC-MS investigations of the crude EtOAc extract revealed the presence of geosmin identified by comparison with computerized library data. The characteristic odour of the broth was due to a mixture of geosmin and albaflavenone. The powerful odour of pure albaflavenone is best described as earthycamphor-like.

\section{Biological Activity}

Pure albaflavenone was active against Bacillus subtilis. In the serial dilution assay the MIC for albaflavenone was determined as $8 \sim 10 \mu \mathrm{g} / \mathrm{ml}$. Further studies of the antimicrobial activity are in progress.

\section{Discussion}

The strain DSM 5415 was characterised by a novel morphology, which has not previously been described for a streptomycete. Long ropes of mycelium and spore chains were formed on a range of media. A further isolate, DSM 6012 was found with the same morphology. Studies of this strain are in progress. Strain DSM 5415 had an atypical menaquinone composition. Major amounts of MK9(H4) were detected. Broth cultures of DSM 5415 had a strong and characteristic odour originating from the sesquiterpenes 
geosmin and albaflavenone. The latter is an unusual, odorous, volatile metabolite with antibacterial activity.

\section{Acknowledgments}

The menaquinone content was determined by REINER KROPPENSTEDT of the DSM. We are indebted to Mr. BENT Ole Petersen for measuring and analyzing the NMR data and to Dr. S. E. Harnung for the determination of the CD data measured on a modified JASCO 710 instrument financed by the Danish Natural Science Research Counsil, grant $\# / /-0373-1$.

\section{References}

1) Gerber, N. N.: Volatile substances from Actinomycetes: their role in the odour pollution of water. C. R. C. Crit. Rev. Microbiol. 7: $191 \sim 214,1979$

2) Weet, J.; W. Y. Huang \& J. L. LASETER: Streptomyces sp: a source of odorous substances in potable water. Water, Air and Soil Pollution 11: 217 223, 1979

3) Buttery, R. G. \& J. A. Garibald: Geosmin and methyliso-borneol in garden soil. J. Agric. Food Chem. 24: $1246 \sim 1247,1976$

4) GERBER, N. N.: Three highly odorous metabolites from an actinomycete: 2-isopropyl-3-methoxy-pyrazine, methyliso-borneol and geosmin. J. Chem. Ecol. 3: 475 482, 1977

5) Gerber, N. N.: Sesquiterpenoids from actinomycetes: cadin-4-ene-1-ol. Phytochemistry 10: 185 189, 1971

6) Gerber, N. N.: Sesquiterpenoids from actinomycetes. Phytochemistry 11: 385 388, 1972

7) Dougherty, J. D.; R. D. Campbell \& R. L. Morris: Actinomycete: isolation and identification of agent responsible for musty odors. Science 152: 1372 1373, 1966

8) KoE, B. K.; B. A. Sobin \& W. D. Celmer: PA 132; a new antibiotic. I. Isolation and chemical properties. Antibiot. Annu. 672 675, 1956 1957

9) Cane, D. E.; J. S. Oliver, P. H. M. Harrison, C. Abell, B. R. Hubbard, C. T. Kane \& R. Lattman: Biosynthesis of pentalenene and pentalenolactone. J. Am. Chem. Soc. 112: 4513 4524, 1990

10) Williams, S. T. \& E. M. H. Wellington: Actinomycetes. In Methods of Soil Analysis. Part 2. Chemical and Microbiological Properties. 2nd edit. Ed., A. I. PAGE et al., pp 969 987. Amer. Soc. Agronomy Soil Science Soc. America Inc. Pub. Madison, Wisconsin, U.S.A., 1982

11) Hirsch, C. F. \& D. L. Christensen: Novel method for selective isolation of actinomycetes. Appl. Env. Microbiol. 46: $925 \sim 929,1983$

12) Williams, S. T.; M. Goodfellow, E. M. H. Wellington, J. C. Vickers, G. Alderson, P. H. A. Sneal.h, M. J. SACkin \& A. M. Mortimer: A probability matrix for identification of some streptomycetes. J. Gen. Microbiol. 129: $1815 \sim 1830,1983$

13) Stackebrandt, E.; D. Witt, C. Kemmerling, R. Kroppenstedt \& W. Liesack: Designation of streptomycete $16 S$ and $23 S$ rRNA-based target regions for oligonucleotide probes. Appl. Env. Microbiol. 57: 1468 1477, 1991

14) StAneck, J. L. \& G. D. RobERTS: Simplified approach to identification of aerobic actinomycetes by thin layer chromatography. Appl. Microbiol. 28: 226 231, 1974

15) Williams, S. T.; M. Goodfellow \& Alderson: Genus Streptomyces Waksmans \& Henrici 1943, 339AL. In Bergey's Manual of Systematic Bacteriology, Vol. 4. Eds. S. T. Williams, M. E. Sharp \& J. G. HolT, pp. 2452 2492, The Williams \& Wilkins Co., Baltimore, 1989

16) BAX, A. \& S. SUbramanian: sensitivity-enhanced two-dimensional heteronuclear shift correlation NMRspectroscopy. J. Magn. Res. 67: 565 569, 1986

17) Stavely, H. E. \& G. N. Bollenback: Steroids with double bonds between quaternary carbon atoms. I. The oxidation of $\alpha$-ergostenyl acetate. J. Am. Chem. Soc. 65: 1285 1289, 1943

18) Andersen, N. H.; S. E. SMith \& Y. OHTA: Rearrangement of zizaene-related sesquiterpenes. J. Chem. Soc. Chem. Comm. 1973: 447 448, 1973 